\title{
ATTENUATION OF PARAQUAT-INDUCED NEPHROTOXICITY AND DYSFUNCTION IN MALE WISTAR ALBINO RATS
}

\author{
C.O. Ujowundu*, P.I. Anaba, N.B. Ulinasombu, F.N. Ujowundu, K.O. Igwe, H.D. Ogbuagu \\ Federal University of Technology, Owerri, Nigeria \\ *Corresponding author: ujowundu@yahoo.com, cujowundu@futo.edu.ng \\ Received 31 December 2019; Accepted 12 February 2020
}

\begin{abstract}
Background. Paraquat (PQ) is a pesticide commonly used in the control of weed in agricultural practices worldwide. Exposure to PQ has adverse biochemical and physiological consequences to humans and animals. The mechanism of toxicity is linked to the generation of reactive oxygen species and subsequent lipid peroxidation. Presently, no single effective antidote to PQ toxicity has been established. Therefore, the need to continually investigate different treatment approaches is of paramount importance.

Objective. This study evaluated the capacity of selected dietary supplements to attenuate paraquat-induced kidney dysfunction and damages by determining some kidney function biomarkers and oxidative parameters. Methods. Thirty-six Wistar albino rats were randomly separated into six groups. Each group (except Normal control) was intoxicated every other day with $1.5 \mathrm{mg} / \mathrm{kg}$ body weight of PQ and four groups (except PQ and Normal control groups) were treated daily with $40 \mathrm{mg} / \mathrm{kg}$ of garlic, glutathione and vitamin $\mathrm{C}$ for two weeks. Results. The results showed significant $(p<0.05)$ increases in concentration of kidney malondialdehyde, urea, creatinine, and blood lipid profiles. Also, significant decrease in concentrations of high-density lipoprotein cholesterol, kidney glutathione and total antioxidant capacity were presented by PQ control group compared to other PQ exposed groups treated with the antioxidant compounds.

Conclusions. PQ-induced changes indicated kidney dysfunction and damage. However, the administration of antioxidant supplements attenuated the PQ-induced biochemical and physiological dysfunction in the rats.

Keywords: paraquat; herbicide; nephrotoxicity; xenobiotics; antioxidants.
\end{abstract}

\section{Introduction}

Paraquat (PQ) herbicide is a quaternary nitrogen compound (1,1'-dimethyl-4,4'-bipyridinium dichloride). It is a common non-selective contact herbicide used in agricultural practice worldwide $[1,2]$. PQ is a known human and animal xenobiotic and it is highly active leading to several cases of acute poisoning and death $[3,4]$. The toxicity of PQ necessitated the classification as moderately hazardous herbicide and class II poison for acute toxicity [5].

Studies have shown that oral ingestion of PQ induces generation of hydrogen peroxide anion, hydroxyl free radical as well as superoxide anions which cause lipid peroxidation with resultant cell membrane damage. These biochemical activities caused by oxidative free radicals are a common pathway for kidney damage and renal tubular necrosis. Aside from the potential for nephrotoxicity PQ exposure can result in hepatotoxicity and pulmonary fibrosis as well as systemic effects [6].

Systemic presence of PQ elicits generation of reactive oxygen species (ROS), accompanied by lipid peroxidation. This assertion is supported by epidemiological and clinical evidences which attribute mammalian biochemical and physiological changes such as skin cancer and other tumors [7, 8], lung injuries [9], to PQ intoxication.

The increased advocacy for the use of herbicide in crop production makes it important to regularly ascertain the consequences of different levels of pesticides in the environment especially remnant of pesticides in food and water. Since PQ is one of the widely accepted herbicides, this study becomes imperative. PQ exerts its toxic effects by inducing oxidative stress on organisms. Different treatment measures have been adopted and yet no effective antidote has been found [9]. Due to the need to find an effective remedy to PQ-induced renal damage and dysfunction, this study used dietary supplements such as vitamin C, glutathione and garlic [10-13]. Vitamin C, glutathione and constituents of garlic exhibit antioxidant potentials that can reverse PQinduced nephrotoxicity and dysfunction using male Wistar albino rats.

\section{Materials and Methods}

\section{Dietary supplements}

The supplements used in this study were purchased from Orchard Pharmaceuticals, Ikenegbu 
Owerri, Imo State, Nigeria. L-Glutathione (L-reduced) was manufactured by Raphe Pharmaceutiques Laboratoires, Dallas Texas USA. It is a certified supplement from nature lot\#201604. Vitamin C (ascorbic acid) and Garlic tablet (Allium sativum) were manufactured in the USA for: Mason Vitamins, Inc. Miami Lakes, FL 33014, 1-888-860-5376 (www.MasonVitamins.com) The supplements were prepared in normal saline for oral administration.

\section{Study animals}

Thirty-six male Wistar albino rats weighing $150 \pm 10 \mathrm{~g}$ were obtained from the Department of Veterinary Medicine, University of Nigeria Nsukka, Enugu State, Nigeria. The rats were kept in cages, maintained at a room temperature of $25 \pm 2{ }^{\circ} \mathrm{C}$, $12 \mathrm{~h}$ light/dark cycle, and allowed free access to rat chow and water.

\section{Study design}

After seven days of acclimatization, the rats were randomly allocated to six cages of six rats each, housed in the animal house of the Department of Biochemistry, Federal University of Technology, Owerri (FUTO). Each group was treated as follows: saline.

Group 1 (normal control) received normal

Group 2 (PQ control) received $1.5 \mathrm{mg} / \mathrm{kg}$ body weight (bw) of PQ.

Group 3 received $1.5 \mathrm{mg} / \mathrm{kg}$ bw of $\mathrm{PQ}$ and $40 \mathrm{mg} / \mathrm{kg}$ bw of vitamin C.

Group 4 received $1.5 \mathrm{mg} / \mathrm{kg}$ bw of PQ and $40 \mathrm{mg} / \mathrm{kg}$ bw of garlic.

Group 5 received $1.5 \mathrm{mg} / \mathrm{kg}$ bw of PQ and $40 \mathrm{mg} / \mathrm{kg}$ bw of glutathione.

Group 6 received $1.5 \mathrm{mg} / \mathrm{kg}$ bw of PQ and $40 \mathrm{mg} / \mathrm{kg}$ bw of vitamin C, glutathione, and garlic in the ratio of $1: 1: 1$.

PQ was administered intraperitoneally at two days interval and other supplements orally administered daily for the two weeks. All rats were allowed free access to rat chow and clean water and no death was recorded for the two weeks duration of the study. This study was approved (FUTO/BCH/EC/2017/25) by the Ethics committee of the Department of Biochemistry, FUTO and it observed the guidelines of the National Institute of Health [14].

\section{Collection of tissue samples}

After 14 days of study, blood samples were collected by ocular puncture into non-anticoagulant test tubes. Serum was obtained by allowing the blood samples to clot, centrifuged at $3000 \times g$ for $15 \mathrm{~min}$ and stored at $4{ }^{\circ} \mathrm{C}$ until used for analyses. Furthermore, the rats were sacrificed and kidney samples obtained and divided into two parts. A portion was washed in cold saline, homogenized in $1.15 \% \mathrm{KCl}$ in EDTA/pH 7.4, centrifuged for $20 \mathrm{~min}$ at $250 \times \mathrm{g}$ and aliquots of the supernatant used for biochemical assays. The other portions of the kidney sample were stored in $0.5 \%$ formaldehyde for histopathology studies.

\section{Determination of some oxidative stress para- meters}

Malondialdehyde was determined by the method of Wallin et al. [15]. Four test tubes were prepared and aligned in a rack, and $0.1 \mathrm{ml}$ of sample, $0.9 \mathrm{ml}$ of distilled water, $0.5 \mathrm{ml}$ of $25 \%$ trichloroacetic acid (TCA) and $0.5 \mathrm{ml}$ of $17 \%$ TBA in $0.3 \% \mathrm{NaOH}$ were delivered into the test tubes. The mixture was incubated at $95^{\circ} \mathrm{C}$ for 40 minutes and cooled in water bath afterward. Also, $0.1 \mathrm{ml}$ of $20 \%$ sodium dodecyl sulphate was added to the mixture. The concentration of malondialdehyde was determined from the absorbance read at $532 \mathrm{~nm}$ from the mixture and blank.

The concentration of glutathione was determined by the method described by Raja et al. [16]. Briefly: an equal amount of the homogenate was mixed with $10 \%$ trichloroacetic acid and centrifuged to separate the proteins. Then $0.01 \mathrm{ml}$ of the supernatant was pipetted, $2 \mathrm{ml}$ of phosphate buffer $(\mathrm{pH} 8.4), 0.5 \mathrm{ml}$ of 5, 5-dithiobis (2-nitrobenzoic acid), and $0.4 \mathrm{ml}$ doubled distilled water was added to the test tubes. The mixture was vortexed and the absorbance was read within 15 minutes using a spectrophotometer. Absorbance of GSH was calculated from the standard calibration curve $(y=m x)$.

Total antioxidant activity was determined by the Ferric reducing ability of Plasma (FRAP) method by Benzie and Strain [17]. Initially, a working reagent comprising acetate buffer $(\mathrm{pH} 3.6)$, ferric chloride and tripyridyltriazine in the ratio of 10:1:1 respectively was prepared. To three test tubes containing $60 \mu \mathrm{l}$ of the sample, standard and blank, $1.8 \mathrm{ml}$ of working reagent was added. The reaction mixture was mixed thoroughly and incubated at $37^{\circ} \mathrm{C}$ for 10 minutes. The resulting blue-colored solution was read at $593 \mathrm{~nm}$. The blank contained distilled water and the standard solution contains $1000 \mu \mathrm{mol} / \mathrm{l}$ of ferrous sulfate.

Commercial test kits of BioSystems S.A. Costa Brava, 30. 08030 Barcelona (Spain) was used to determine serum creatinine and urea. Similarly, BioSystems, test kits were used to determine serum 
triacylglycerides (TAG), cholesterol, high-density lipoprotein (HDL) and low-density lipoprotein (LDL). Randox Laboratories Ltd (Antrim, United Kingdom) commercial test kits were used to determine serum nitric oxide and uric acid concentration.

\section{Histopathological studies}

The fixed portions of kidney samples were dehydrated and allowed to undergo dealcoholization, infiltration and embedded in paraffin as shown by Okoro [18] with little modifications. Furthermore, the kidney samples were sectioned (serially) at an appropriate thickness, stained with hematoxylin and eosin [19]. Finally, a light microscope was utilized to examine tissue sections at a magnification of $100 \times$ and $400 \times$.

\section{Statistical analysis}

SPSS version 23 was used to analyze the data collected. The data were subjected to one-way analysis of variance (ANOVA) at $p<0.05$. The results were expressed as mean \pm standard deviation of quadruple determination.

\section{Results}

Fig. 1 shows a significant increase in the concentration of kidney malondialdehyde of animals exposed to PQ when compared to the normal control group which has the lowest concentration of

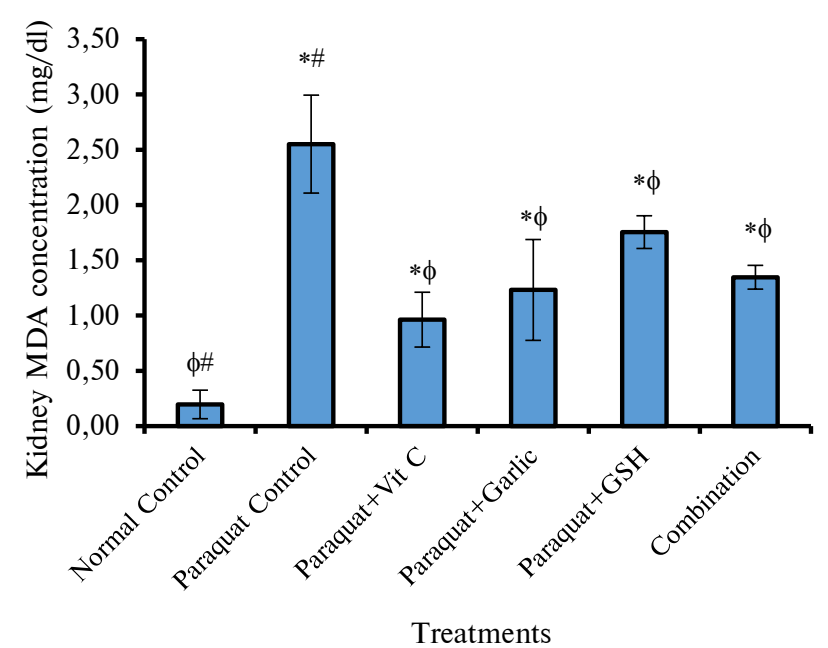

Figure 1: Concentration of kidney malondialdehyde (MDA) of albino Wistar rats exposed to paraquat and treated with supplements. Bars represent mean \pm standard deviation of quadruple determinations; ${ }^{*}, \phi$, \# - statistical difference between groups $(p<0.05):{ }^{*}-$ compared to the Normal control group, $\phi-$ compared to paraquat control, \# - compared to supplement treatments malondialdehyde. Treatment with supplements significantly reduced MDA concentration of animals exposed to PQ. The concentration of reduced glutathione (GSH) (Fig. 2), was lowest in PQ control group when compared to the normal control group. However, kidney concentration of GSH was significantly higher in vitamin $\mathrm{C}, \mathrm{GSH}$ and combination groups compared to PQ control. The TAC (Fig. 3) was lowest in the PQ control group compared to the normal control group. The concentrations of kidney total antioxidant capacity were significantly increased in groups that received the supplements concomitantly. Aside from the concentration of nitric oxide (Fig. 7), the serum concentration of urea, creatinine and uric acid (Figs. 4 to 6) of PQ exposed rats were significantly increased compared to normal control rats. However, supplement treated groups presented urea, creatinine and uric acid concentrations which are within that of normal control rats.

Rats administered PQ presented significantly increased serum cholesterol, triacylglyceride and low-density lipoprotein-cholesterol concentrations (Figs. 8 to 10). However, rats administered the supplements showed reduced concentration of some blood lipids with vitamin $\mathrm{C}$ and garlic groups presenting significantly reduced cholesterol, triacylglycerol, and LDL-cholesterol when compared to the PQ control group. Furthermore, HDL-cholesterol was significantly reduced in PQ control (Fig. 11) compared to the normal control and the supplement treated groups.

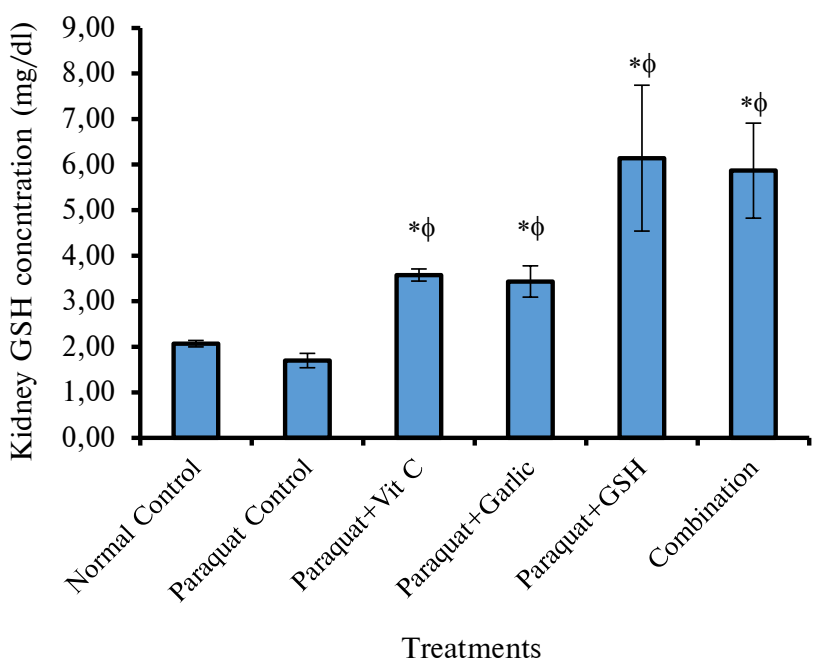

Figure 2: Concentration of kidney glutathione (GSH) of albino Wistar rats exposed to paraquat and treated with supplements. Bars represent mean \pm standard deviation of quadruple determinations; ${ }^{*}, \phi$, \# - statistical difference between groups $(p<0.05)$ : * - compared to the Normal control group, $\phi-$ compared to paraquat control, \# - compared to supplement treatments 


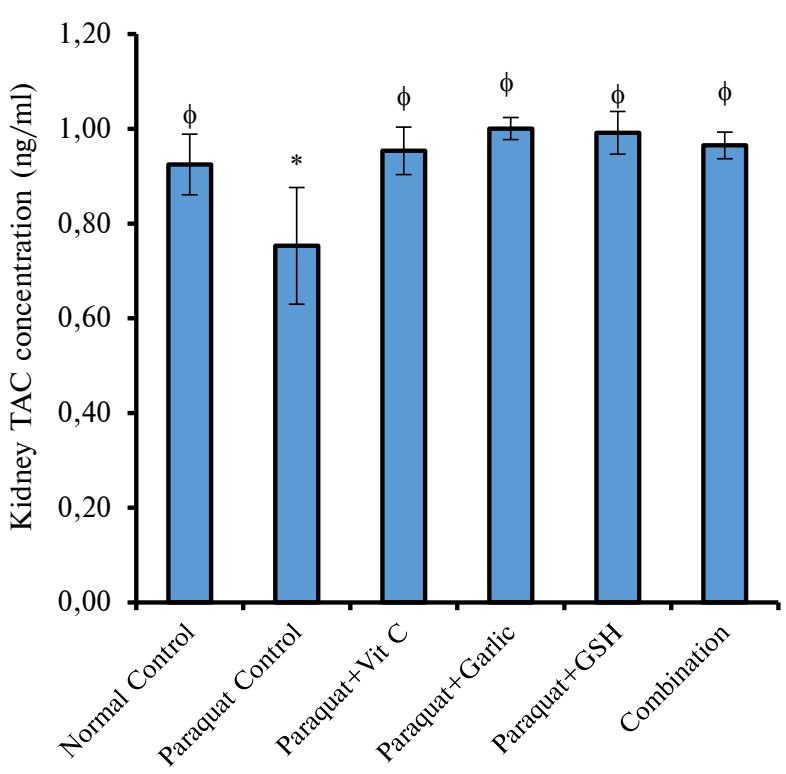

Treatments

Figure 3: Concentration of kidney total antioxidant capacity (TAC) of albino Wistar rats exposed to paraquat and treated with supplements. Bars represent mean \pm standard deviation of quadruple determinations; $*, \phi, \#-$ statistical difference between groups $(p<0.05):{ }^{*}$ - compared to the Normal control group, $\phi-$ compared to paraquat control, \# - compared to supplement treatments

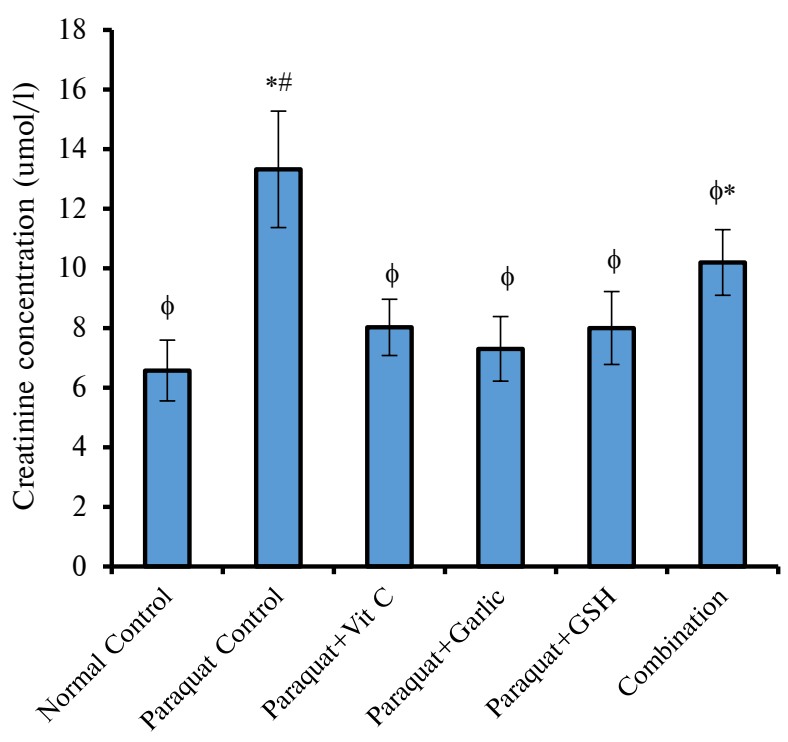

Treatments

Figure 5: Concentration of creatinine of albino Wistar rats exposed to paraquat and treated with supplements. Bars represent mean \pm standard deviation of quadruple determinations; ${ }^{*}, \phi$, \#statistical difference between groups $(p<0.05):{ }^{*}-$ compared to the Normal control group, $\phi-$ compared to paraquat control, \# - compared to supplement treatments

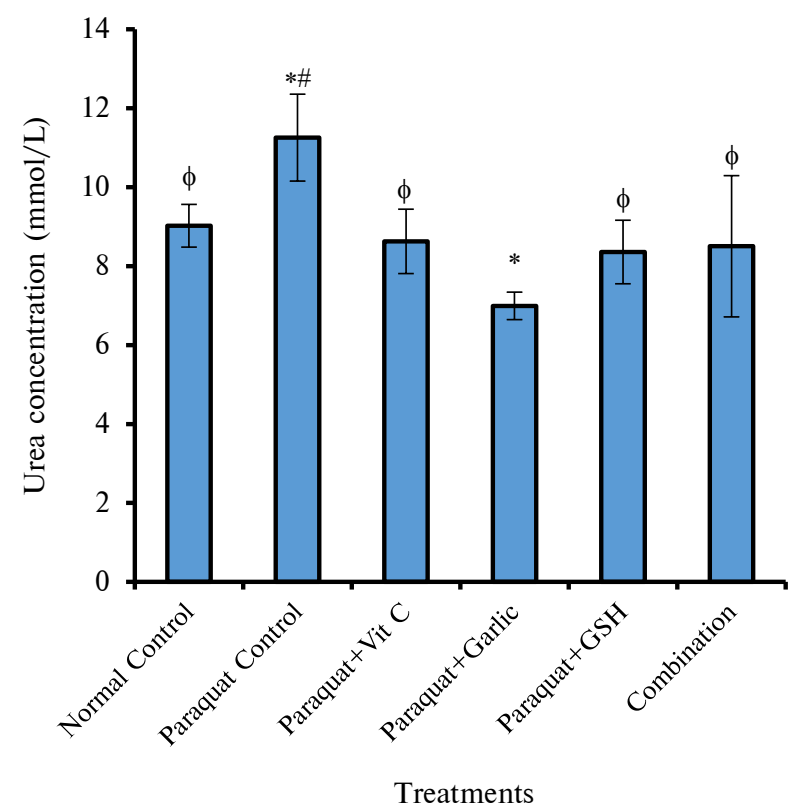

Figure 4: Concentration of urea of albino Wistar rats exposed to paraquat and treated with supplements. Bars represent mean \pm standard deviation of quadruple determinations; * $\phi$, \# - statistical difference between groups $(p<0.05)$ : * - compared to the Normal control group, $\phi-$ compared to paraquat control, \# - compared to supplement treatments

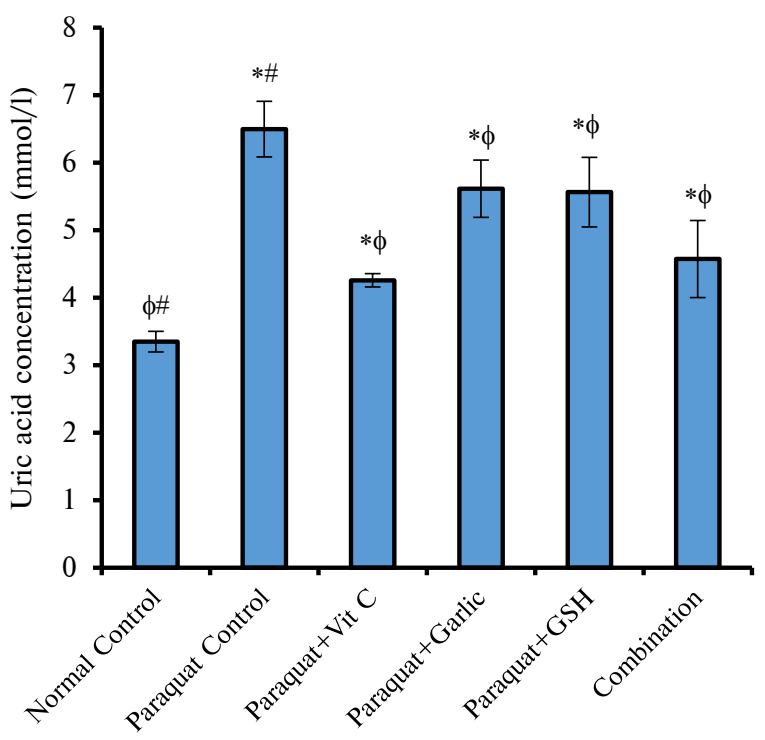

Treatments

Figure 6: Concentration of uric acid of albino Wistar rats exposed to paraquat and treated with supplements. Bars represent mean \pm standard deviation of quadruple determinations; *, $\phi$, \# statistical difference between groups $(p<0.05):{ }^{*}-$ compared to the Normal control group, $\phi-$ compared to paraquat control, $\#$ - compared to supplement treatments 


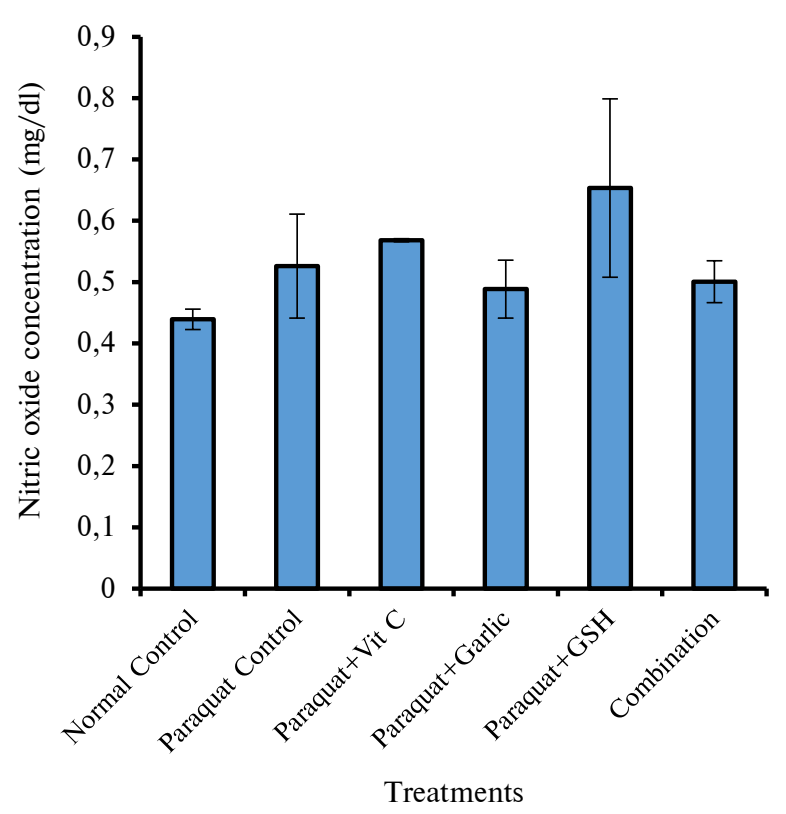

Figure 7: Concentration of nitric oxide of albino Wistar rats exposed to paraquat and treated with supplements. Bars represent mean \pm standard deviation of quadruple determinations; *,$\phi$, \# statistical difference between groups $(p<0.05):{ }^{*}-$ compared to the Normal control group, $\phi-$ compared to paraquat control, \# - compared to supplement treatments

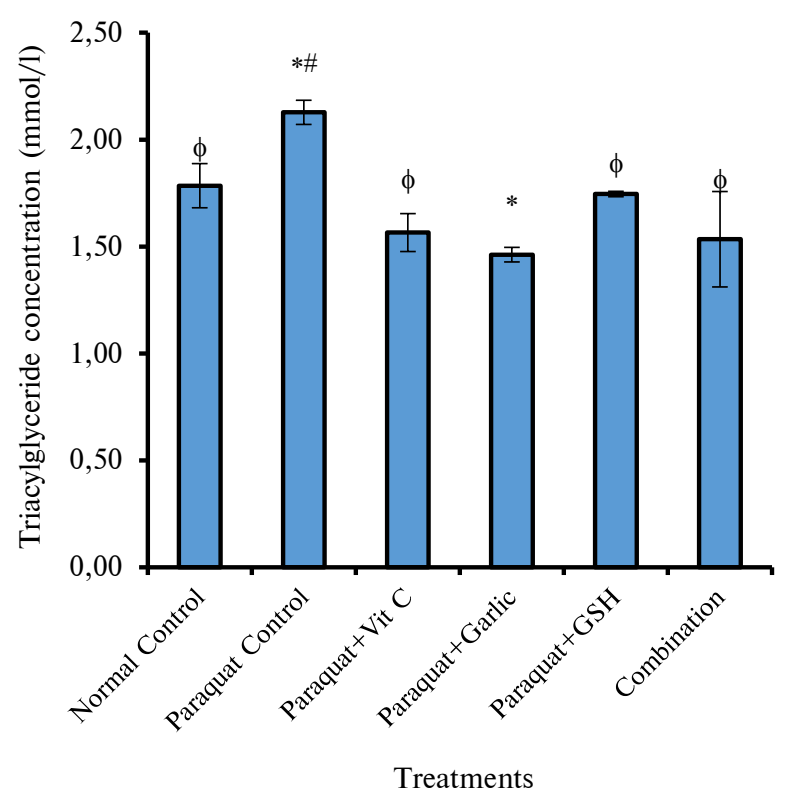

Figure 9: Triacylglyceride concentration of albino Wistar rats exposed to paraquat and treated with supplements. Bars represent mean \pm standard deviation of quadruple determinations; ${ }^{*}, \phi$, \#statistical difference between groups $(p<0.05): *$ - compared to the Normal control group, $\phi-$ compared to paraquat control, \# - compared to supplement treatments

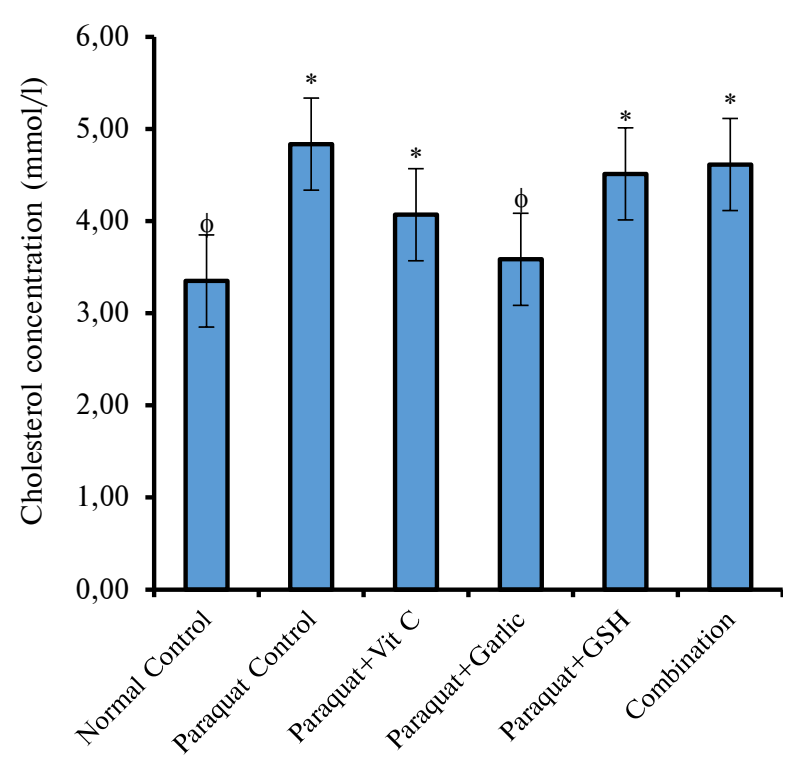

Treatments

Figure 8: Cholesterol concentration of albino Wistar rats exposed to paraquat and treated with supplements. Bars represent mean \pm standard deviation of quadruple determinations; ${ }^{*}, \phi$, \# - statistical difference between groups $(p<0.05):{ }^{*}-$ compared to the Normal control group, $\phi-$ compared to paraquat control, \# - compared to supplement treatments

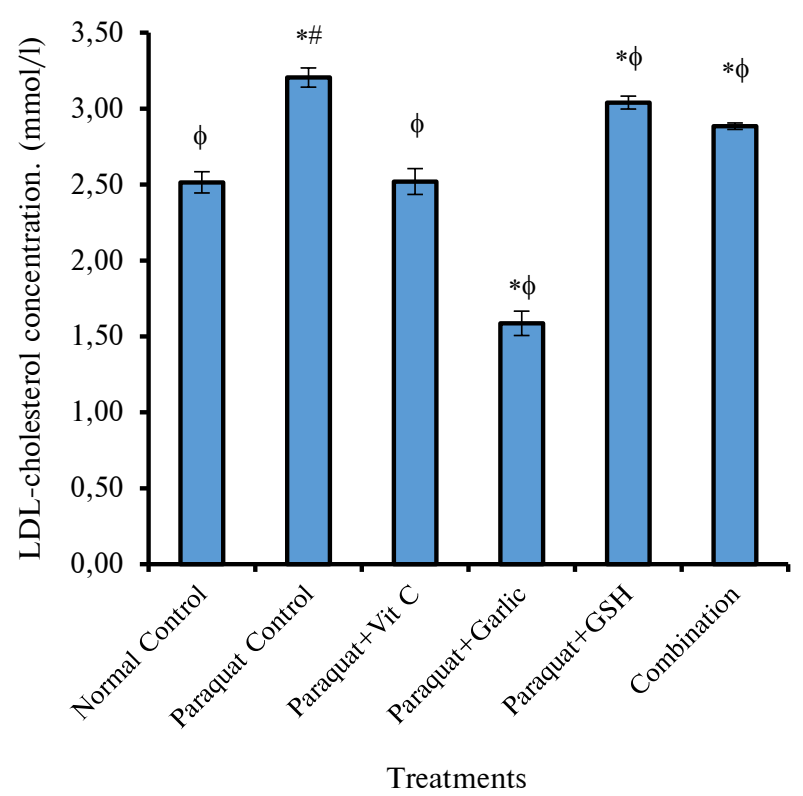

Figure 10: Low-density lipoprotein (LDL)-cholesterol concentration of albino Wistar rats exposed to paraquat and treated with supplements. Bars represent mean \pm standard deviation of quadruple determinations; *, $\phi$, \# - statistical difference between groups $(p<0.05)$ : ${ }^{*}$ - compared to the Normal control group, $\phi$ - compared to paraquat control, \# - compared to supplement treatments 


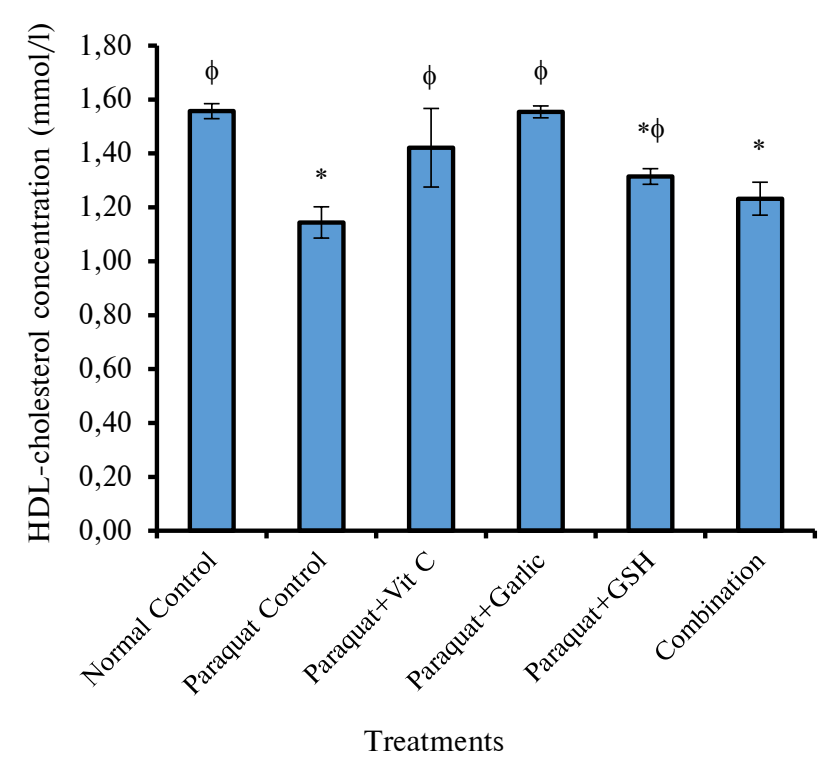

Figure 11: High-density lipoprotein(HDL)-cholesterol concentration of albino Wistar rats exposed to paraquat and treated with supplements. Bars represent mean \pm standard deviation of quadruple determinations; $*, \phi, \#-$ statistical difference between groups $(p<0.05):{ }^{*}-$ compared to the Normal control group, $\phi-$ compared to paraquat control, \# - compared to supplement treatments

The kidney sections are presented in Fig. 12: $\mathrm{NC}$ : section shows a renal corpuscle with normal glomerulus $(G)$, intraglomerular space (IG) and proximal convoluted tubule (PCT). PQC: section shows renal tissue with shrunken glomerulus $(\mathrm{G})$ and widened intraglomerular space (IG) and proximal convoluted tubules(PCT). VTC: section shows slightly shrunken glomerulus $(G)$ and intraglomerular space (IG) and a mild increase in proximal convoluted tubule (PCT). GAL: section shows renal corpuscle with normal glomerulus $(\mathrm{G})$ and intraglomerular space (IG), proximal convoluted tubules (PCT) also appeared normal. GSH: section presents slightly shrunken glomerulus $(G)$ and slightly widened intraglomerular space (IG), the proximal convoluted tubule (PCT) appeared normal. COMB: section shows renal corpuscle with slightly shrunken glomerulus $(\mathrm{G})$, slightly dilated intraglomerular space (IG) and proximal convoluted tubules (PCT) slightly dilated.

\section{Discussion}

Kidney is involved in the body's regulation of numerous biochemical activities especially the excretion of waste and toxic substances. In the current study, the use of garlic, glutathione and vitamin $\mathrm{C}$ to protect cells and tissues from PQ-induced toxicity

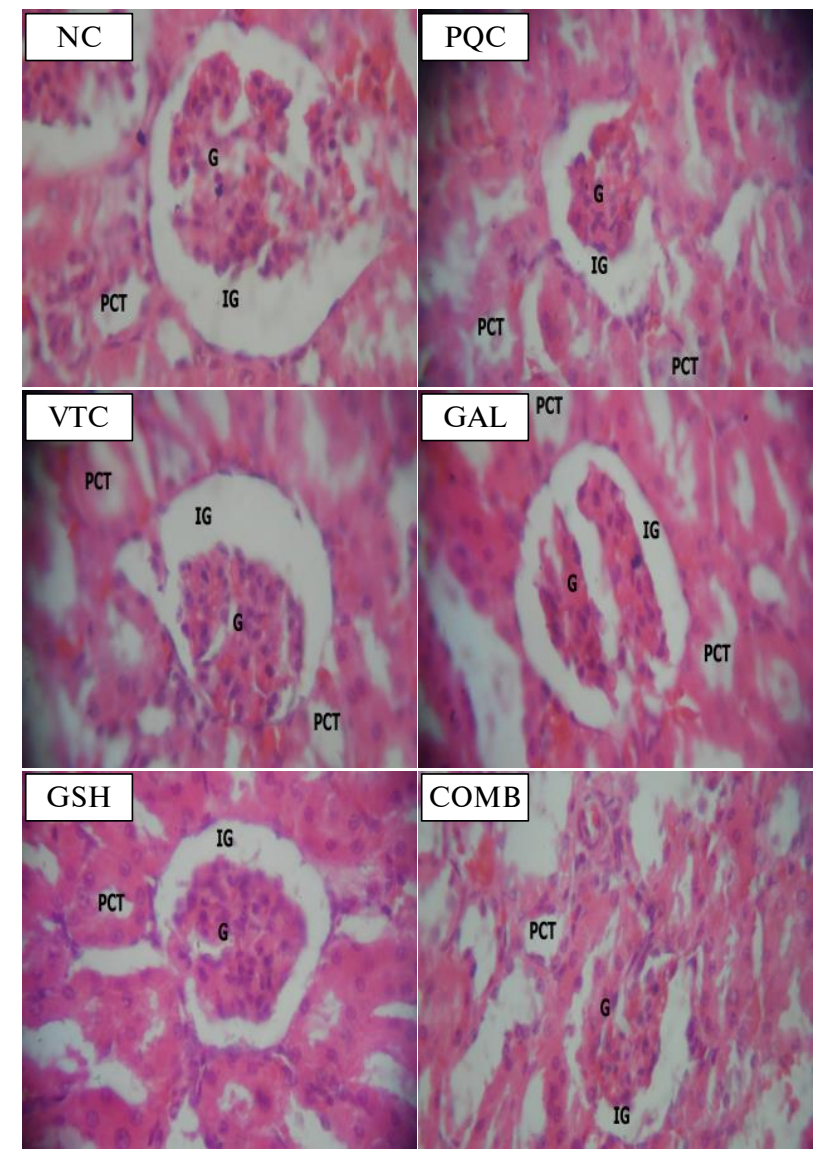

Figure 12: Kidney sections of Wistar albino rats exposed to paraquat and treated with nutritional supplements

highlights the significant role of antioxidants in mitigating the damaging effects of oxidative stress on (kidney) tissues. There were differences in the concentration of kidney malondialdehyde, total antioxidant capacity, glutathione on the supplement treated groups when compared to the PQ-exposed/untreated control group.

In this study the significant increase in malondialdehyde indicates increased lipid peroxidation in groups exposed to $\mathrm{PQ}$, thereby implicating $\mathrm{PQ}$ as an agent of oxidative stress. This result corroborates previous findings which states that free radicals interact with the polyunsaturated fatty acids present in the phospholipid portion of the cell membrane [20] provoking tissue injury [21]. Similarly, the significantly decreased glutathione (GSH) concentration further indicates exposure of rats to PQ-induced oxidative stress. The decrease of GSH concentration might be due to its overwhelming utilization to neutralize excessively produced free radicals [22]. The low GSH concentration agrees with the significant reduction measured for TAC in PQ exposed groups. This confirms the role of free radical generation and 
attenuation of antioxidant levels in PQ-intoxicated rats and this can result in renal injury. This is in agreement with the findings that $\mathrm{PQ}$ alters the oxidative state indices in exposed animals [23]. The continued exposure to PQ as seen in pesticide remnants in foods and water [24] and as applied in this study is pathogenesis to diverse adverse biochemical changes in kidneys of animals, which could lead to renal dysfunction [25].

Rats administered the supplements showed significantly reduced concentration of malondialdehyde. Similarly, the concentration of GSH and TAC have significantly increased in all supplements treated groups. These findings are in agreement with studies that showed that vitamin $\mathrm{C}$ ameliorated a pesticide (deltamethrin)-induced toxicity [26] and garlic partially prevented $\mathrm{PQ}$-induced impairment of renal function [27]. Vitamin $\mathrm{C}$ is an important nonenzymatic antioxidant known to protect cells of the body against oxidants. The inclusion of vitamin $\mathrm{C}$ as one of the supplements in the present study was due to previous reports which indicated that PQ and some xenobiotics induce low vitamin $\mathrm{C}$ levels, and this causes renal toxicity $[28,29]$. The present study shows that vitamin $\mathrm{C}$ treated group presented significantly reduced MDA, urea, creatinine, uric acid, triacylglyceride, and LDL-cholesterol. Parameters such as GSH, TAC, and HDL-cholesterol were significantly increased in Vitamin $\mathrm{C}$ group compared to PQ control.

The significantly increased urea and creatinine concentrations in PQ control rats indicate pathology associated with tissue breakdown [30-32]. These two parameters are biomarkers of renal toxicity [33] and the increase indicate renal damage associated with increased urea production. This is in line with previous reports [34, 35]. However, garlic supplementation showed the significant ameliorative potential to the abnormal urea and creatinine production as presented by rats in the garlic group. However, rats supplemented with vitamin $\mathrm{C}$ presented the most significant reduction in uric acid in all $\mathrm{PQ}$ exposed groups. The fluctuation in nitric oxide concentration showed none significant variation compared to the normal control.

The variations in blood lipid concentration corroborate studies which indicate that toxicants induce reactive oxygen species (ROS) generation. And this elicits oxidative damage that results in various fluctuations of pathophysiological processes and disease induction [36, 37]. The adverse fluctuations in the lipid profile in the present study affirm the observed increase in MDA concentration in PQ exposed rats which indicate oxidative stress induced by oxygen-derived free radicals. This oxidative state causes disturbance in the pro-oxidant and antioxidant balance, which may cause functional cell damage and adverse biological reactions such as dyslipidemia [38]. Antioxidants, as provided by the supplements, can prevent, protect and repair free-radical-mediated damage. Garlic is an important source of allicin, an organosulfur compound, which changes quickly into various sulfur-containing compounds such as diallyl tetrasulfide, diallyl trisulphide, disulfide derivatives, etc. capable of scavenging hydroxyl radicals, preventing lipid peroxidation and altering antioxidant and membrane-bound enzymes in toxicant-exposed rats [39]. The decreased HDL-cholesterol indicates the adverse effect of PQ-induced dyslipidemia which disturbs biological functions of HDL-cholesterol [40]. However, the HDL-cholesterol concentration showed no significant difference between control and supplement treated groups, implying that the supplements may have enhanced clearance of bad cholesterol from the system. HDLcholesterol functions by transporting excess cholesterol derived from peripheral tissues to the liver and exchanges proteins and lipids with chylomicrons and VLDL.

The results of this study indicate that PQ induced some adverse histological changes in kidney of exposed rats. Examination of the kidney section of PQ control (PQC) showed significant alteration in the glomerulus, intraglomerular space and proximal convoluted tubules. These could lead to tubular degeneration and glomerular disruption, and eventually necrosis. These results are similar to previous studies that indicated that PQ can induce kidney damage and dysfunctions [4, 33, 41]. Kidney histology results further support the dysfunction as observed in increased serum creatinine concentration which indicated a decrease in kidneys glomerular filtration rate (GFR). This will ultimately impair renal function with a consequential reduction in the rate of renal clearance. This may further increase the systemic concentration of $\mathrm{PQ}$, increase the toxicity, and cause other organ dysfunctions [42, 43].

\section{Conclusions}

This study demonstrated that exposure to PQ herbicide can induce nephrotoxicity by a mechanism associated with the generation of hydroxyl free radical, hydrogen peroxide anion and superoxide anion, which result in exhaustion of cellular NADPH and lipid peroxidation of cellular membranes of kidneys. The adverse biochemical consequences of PQ poisoning indicated that provision of antioxidants 
stimulates some level of amelioration. It was in this regard that this study administered garlic, vitamin $\mathrm{C}$ and glutathione as antioxidant supplements to PQ- exposed rats. These supplements acted as potent agents for the attenuation of PQ-induced renal dysfunction and pathological damages.

\section{References}

[1] Raghu K, Mahesh V, Sasidhar P, Reddy PR, Venkataramaniah V, Agrawal A. Paraquat poisoning: A case report and review of literature. J Family Commun Med. 2013;20:198-200. DOI: 10.4103/2230-8229.122023

[2] Lalruatfela PL, Saminathan M, Ingole RS, Dhama K, Joshi MV. Toxicopathology of paraquat herbicide in female Wistar rats. Asian J Animal Vet Adv. 2014;9:523-42. DOI: 10.3923/ajava.2014.523.542

[3] Dawson AH, Eddleston M, Senarathna L, Mohamed F, Gawarammana I, Bowe SJ, et al. Acute human lethal toxicity of agricultural pesticides: A prospective cohort study. PLoS Med. 2010;7(10):e1000357. DOI: 10.1371/journal.pmed.1000357

[4] Akinloye OA, Abioye OA, Olaojoyetan OE, Awosika OT, Akinloye DI. Dose-dependent effects of paraquat on C-reactive protein, some lipid profile parameters and histology of tissues in male albino rats. Ife J Sci. 2013;15(1):189-95. DOI: $10.4172 / 2168-9652.1000106$

[5] The WHO recommended classification of pesticides by hazard and guidelines to classification. Geneva: World Health Organization; 2009. p. 78.

[6] Suntres ZE. Role of antioxidants in paraquat toxicity. Toxicology. 2002;180:65-77. DOI: 10.1016/s0300-483x(02)00382-7

[7] Coats GE, Funderburk Jr HH, Lawrence JM, Davis DE. Factors affecting persistence and inactivation of diquat and paraquat. Weed Res. 2006;6(1):58-66. DOI: 10.1111/j.1365-3180.1966.tb00867.x

[8] Huggins DR, Reganold JP. No-till: The quiet revolution. Sci Amer. 2008;299(1):70-7. DOI: 10.1038/scientificamerican0708-70

[9] Kamel F. Epidemiology. Paths from pesticides to Parkinson's. Sciense. 2013;341:722-3. DOI: 10.1126/science.1243619

[10] Padayatty SJ, Katz A, Wang Y. Vitamin C as an antioxidant: Evaluation of its role in disease prevention. J Am College Nutr. 2003;22:18-35. DOI: 10.1080/07315724.2003.10719272

[11] Pompella A, Visvikis A, Paolicchi A, DeTata V, Casini AF. The changing faces of protagonist. Biochem Pharmacol. 2003;66:1499-503. DOI: 10.1016/s0006-2952(03)00504-5

[12] Maldonado PD, Alvarez-Idaboy JR, Aguilar-González A, Lira-Rocha A, Jung-Cook H, Medina-Campos ON, et al. Role of allyl group in the hydroxyl and peroxyl radical scavenging activity of allyl cysteine. J Phys Chem B. 2011;115(45):13408-17. DOI: $10.1021 /$ jp208233f

[13] Borlinghaus J, Albrecht F, Gruhlke MC, Nwachukwu ID, Slusarenko AJ. Allicin: Chemistry and biological properties. Molecules. 2014;19:12591-618. DOI: 10.3390/molecules190812591

[14] National Institute of Health (NIH). Guide for the care and use of laboratory animals. DHEW Publication, Office of Science and Health Reports; 1985.

[15] Wallin B, Rosengren B, Shertzer HG, Cameyo G. Lipoprotein oxidation and measurement of TBARS formation in a single microlitre peate: its use for evaluation of antioxidants. Anal Biochem. 1993 Jan;208(1):10-5. DOI: 10.1006/abio.1993.1002

[16] Raja S, Ahmed K, Kumar V, Mukherjee K, Bandyopadhyay A, Mukherjee P. Antioxidant effect of Cytisus scopararius against carbon tetrachloride treated liver injury in rats. J Ehnopharm. 2007;109:41-7. DOI: 10.1016/j.jep.2006.06.012

[17] Benzie IFF, Strain JJ. The ferric reducing ability of plasma (FRAP) as a measure of antioxidant power: The FRAP assay. Anal Biochem. 1996;239:70-6. DOI: 10.1006/abio.1996.0292

[18] Okoro I. Manual of practical histology. 2nd ed. Owerri: Peace Publishers; 2002.

[19] Conn HJ, Darrow MA, Emmels VM. Staining procedures used by the biological stain commission. 2nd ed. Baltimore: Williams \&Wilkins Co.; 1960. p. 93-4.

[20] Spitz DR, Azzam EI, Li JJ, Gius D. Metabolic oxidation/reduction reactions and cellular responses to ionizing radiation: A unifying concept in stress response biology. Cancer Metastasis Rev. 2004;23:311-22. DOI: 10.1023/B:CANC.0000031769.14728.bc

[21] Soliman SM. Protective role of oregano oil against histological changes in whole body gamma irradiated albino rats. J Egypt Ger Soc Zool. 2007;52C:46-56.

[22] Dudley RW, Khairallah M, Mohammed S, Lands L, Des Rosiers C, Petrof BJ. Dynamic responses of the glutathione system to acute oxidative stress in dystrophic mouse (mdx) muscles. Am J Physiol Regul Integr Comp Physiol. 2006 Sep;291(3):R704-10. DOI: 10.1152/ajpregu.00031.2006

[23] Ahmad I, Kumar A, Shukla S, Prasad Pandey H, Singh C. The involvement of nitric oxide in maneb- and paraquat-induced oxidative stress in rat polymorphonuclear leukocytes. Free Radic Res. 2008 Oct;42(10):849-62. DOI: 10.1080/10715760802513733

[24] Ujowundu CO, Nnanna CG, Ndubuisi EU, Ngwu PC, Uzoma CW, Ezeji EU. Glyphosate-based pesticide-induced biochemical changes in hepatic and renal tissues of Clarias gariepinus. FUTO J Series. 2017;1:225-35. 
[25] Abdel-Mageid SA. Structural changes in the kidney of albino rat in response to the administration of paraquat herbicide. J Egypt Germ Soc Zool. 1994;15:153-75.

[26] Mongi S, Mahfoud M, Amel B, Kamel J, Abdelfattah el F. Protective effects of vitamin C against haematological and biochemical toxicity induced by deltamethrin in male Wistar rats. Ecotoxicol Environ Saf. 2011 Sep;74(6):1765-9. DOI: 10.1016/j.ecoenv.2011.04.003

[27] Karima ZW. The influence of vitamin C or selenium on paraquat-induced toxicity in guinea pigs. Pakistan J Biol Sci. 2001;4:81-8.

[28] Valipour P, Heidarian E, Khoshdel A, Gholami-Arjenaki M. Protective effects of hydroalcoholic extract of Ferulago angulata against gentamicin-induced nephrotoxicity in rats. Iran J Kidney Dis. 2016;10(4):189-96.

[29] Sharifi-Rigi A, Heidarian E. Protective and anti-inflammatory effects of silymarin on paraquat induced nephrotoxicity in rats. J Herbmed Pharmacol. 2018;9(1):28-34. DOI: 10.15171/jhp.2019.05

[30] Samai M, Samai HH, Hague T, Naughton D, Chatterjee PK. Novel superoxide dismutase mimetics for protection against paraquat-induced acute renal injury. Sierra Leone J Biomed Res. 2010;2:54-64. DOI: 10.4314/sljbr.v2i1.56608

[31] Lalruatfela PL, Saminathan M, Ingole RS, Dhama K, Joshi MV. Toxicopathology of paraquat herbicide in female Wistar rats. Asian J Animal Vet Adv. 2014;9:523-42. DOI: 10.3923/ajava.2014.523.542

[32] Weiner ID, Mitch WE, Sands JM. Urea and ammonia metabolism and the control of renal nitrogen excretion. Clin J Am Soc Nephrol. 2015 Aug 7;10(8):1444-58. DOI: 10.2215/CJN.10311013

[33] Gao L, Yang S, Liu J, Liu L. Preventive effects of 5-hydroxy-1-methylhydantoin on paraquat-induced nephrotoxicity in rat. Zhonghua Wei Zhong Bing Ji Jiu Yi Xue. 2015;27(4):246-9. DOI: 10.3760/cma.j.issn.2095-4352.2015.04.004

[34] Sener G, Sehirli AÖ, Altunbas HZ, Ersoy Y, Paskaloglu K, Arbak S, et al. Melatonin protects against gentamicin-induced nephrotoxicity in rats. J Pineal Res. 2002;32(4):231-6. DOI: 10.1034/j.1600-079x.2002.01858.x

[35] Gu SY, Yeh TY, Lin SY, Peng FC. Unfractionated bone marrow cells attenuate paraquat-induced glomerular injury and acute renal failure by modulating the inflammatory response. Sci Rep. 2016;6:23287. DOI: 10.1038/srep23287

[36] Chen YW, Yang CY, Huang CF, Hung DZ, Leung YM. Heavy metals, islet function and diabetes development. Islets. 2009;1:169-76. DOI: $10.4161 /$ isl.1.3.9262

[37] Samarghandian S, Azimi-Nezhad M, Shabestari MM, Azad FJ, Farkhondeh T, Bafandeh F. Effect of chronic exposure to cadmium on serum lipid, lipoprotein and oxidative stress indices in male rats. Interdiscip Toxicol. 2015 Sep;8(3):151-4. DOI: $10.1515 /$ intox-2015-0023

[38] Olisekodiaka MJ, Igbeneghu CA, Onuegbu AJ, Oduru R, Lawal AO. Lipid, lipoproteins, total antioxidant status and organ changes in rats administered high doses of cadmium chloride. Med Princ Pract. 2012;21:156-9. DOI: 10.1159/000333385

[39] Pari L, Murugavel P. Diallyltetrasulfide improves cadmium- induced alterations of acetylcholinesterase, ATPases and oxidative stress in brain of rats. Toxicol. 2007;234:44-50. DOI: 10.1016/j.tox.2007.01.021

[40] Toth DF, Wonger H. Clinical chemistry textbook. 3rd ed. Oxford: Oxford University Press; 2003. p. 423.

[41] Damain F, Frank B, Win fried H, Hartmut M, Laus W. Failure of radiotherapy to resolve fatal lung damage due to paraquat poisoning. Chest. 1992;100(4):1164-5. DOI: 10.1378/chest.100.4.1164

[42] Wunnapuk K, Liu X, Peake P, Gobe G, Endre Z, Grice JE, et al. Renal biomarkers predict nephrotoxicity after paraquat. Toxicol Lett. 2013;222(3):280-8. DOI: 10.1016/j.toxlet.2013.08.003

[43] Mohamed F, Buckley NA, Jayamanne S, Pickering JW, Peake P, Palangasinghe C, et al. Kidney damage biomarkers detect acute kidney injury but only functional markers predict mortality after paraquat ingestion. Toxicol Lett. 2015;237(2):140-50. DOI: $10.1016 /$ j.toxlet.2015.06.008

К.О. Уйовунду, П.І. Анаба, Н.Б. Улінасомбу, Ф.Н. Уйовунду, К.О. Ігве, Х.Д. Огбуагу

\section{ЗМЕНШЕННЯ НЕФРОТОКСИЧНОСТІ ТА ДИСФУНКЦІЇ, ІНДУКОВАНИХ ПАРАКВАТОМ, У САМЦІВ ЩУРІВ-АЛЬБІНОСІВ ЛІНІї WISTAR}

Проблематика. Паракват (PQ) - це пестицид, який широко застосовується у світовій сільськогосподарській практиці для боротьби з бур'янами. Він має несприятливі біохімічні та фрізіологічні наслідки для людини і тварин. Механізм токсичної дії пов'язаний з утворенням активних фрорм кисню та подальшим перекисним окисненням ліпідів. На сьогодні не встановлено жодного ефективного антидоту проти токсичності параквату. Тому необхідність постійного вивчення різних підходів до лікування набуває першорядного значення.

Мета. У цьому дослідженні через визначення деяких біомаркерів функції нирок і параметрів окиснення оцінювалась здатність вибраних біологічно-активних добавок зменшувати індуковані паракватом дисфункцію та ураження нирок.

Методика реалізації. Тридцять шість щурів-альбіносів лінії Wistar було випадковим чином розділено на шість груп. Кожну групу (за винятком контрольної) через день піддавали інтоксикації паракватом із розрахунку 1,5 мг PQ/кг маси тіла, а чотирьом групам (крім PQ і контрольної) протягом двох тижнів щодня вводили екстракт часнику, глутатіон і вітамін С у кількості 40 мг/кг маси тіла. 
Результати. Результати дослідження показали достовірне $(p<0,05)$ підвищення концентрації малонового діальдегіду в нирках, сечовини, креатиніну та ліпідного профрілю крові. Також було відзначено достовірне зниження концентрації холестерину ліпопротеїдів високої щільності, глутатіону нирок і загального антиоксидантного потенціалу в контрольній групі PQ порівняно з іншими $P Q$-інтоксикованими групами, яким вводили антиоксидантні композиції.

Висновки. Зміни, викликані паракватом, вказували на дисфункцію та ураження нирок. Однак застосування антиоксидантних добавок зменшувало індуковану паракватом біохімічну та фізіологічну дисфункцію в щурів.

Ключові слова: паракват; гербіцид; нефротоксичність; ксенобіотики; антиоксиданти.

К.О. Уйовунду, П.И. Анаба, Н.Б. Улинасомбу, Ф.Н. Уйовунду, К.О. Игве, Х.Д. Огбуагу

\section{УМЕНЬШЕНИЕ НЕФРОТОКСИЧНОСТИ И ДИСФУНКЦИИ, ИНДУЦИРОВАННЫХ ПАРАКВАТОМ, У САМЦОВ КРЫС-АЛЬБИНОСОВ ЛИНИИ WISTAR}

Проблематика. Паракват (PQ) - это пестицид, который широко применяется в мировой сельскохозяйственной практике для борьбы с сорняками. Он имеет неблагоприятные биохимические и физиологические последствия для человека и животных. Механизм токсического действия связан с образованием активных форм кислорода и последующим перекисным окислением липидов. На сегодняшний день не установлено ни одного эффективного антидота против токсичности параквата. Поэтому необходимость постоянного изучения различных подходов к лечению приобретает первостепенное значение.

Цель. В этом исследовании через определение некоторых биомаркеров функции почек и параметров окисления оценивалась способность выбранных биологически-активных добавок уменьшать индуцированные паракватом дисфункцию и поражение почек. Методика реализации. Тридцать шесть крыс-альбиносов линии Wistar были случайным образом разделены на шесть групп. Каждую группу (за исключением контрольной) через день подвергали интоксикации паракватом из расчета 1,5 мг PQ/кг массы тела, а четырем группам (кроме PQ и контрольной) в течение двух недель ежедневно вводили экстракт чеснока, глутатион и витамин С в количестве $40 \mathrm{mr} / к г$ массы тела.

Результаты. Результаты исследования показали достоверное $(p<0,05)$ повышение концентрации малонового диальдегида в почках, мочевины, креатинина и липидного профиля крови. Также было отмечено достоверное снижение концентрации холестерина липопротеидов высокой плотности, глутатиона почек и общего антиоксидантного потенциала в контрольной группе $P Q$ по сравнению с другими PQ-интоксицированными группами, которым вводили антиоксидантные композиции.

Выводы. Изменения, вызванные паракватом, указывали на дисфункцию и поражение почек. Однако применение антиоксидантных добавок уменьшало индуцированную паракватом биохимическую и физиологическую дисфункцию у крыс.

Ключевые слова: паракват; гербицид; нефротоксичность; ксенобиотики; антиоксиданты. 